\title{
Synthesis Characterization and Antimicrobial Screening of Some New Tetracyclic Amides
}

\author{
ARCHNA SAXENA* ${ }^{*}$ CHANDRA MOHAN SAXENA and HARSH KUMAR MISHRA \\ Department of Chemistry, D.B.S.(P.G.) College, Govind Nagar, \\ Kanpur (U.P.)-208006, India \\ drcmsaxena01@gmail.com
}

Received 6 July 2016 / Accepted 14 August 2016

\begin{abstract}
Some novel new tetracyclic amides were synthesized by the reaction of glycine / cysteine and ethylene diamine with tartaric acid. The new compounds were isolated as crystalline solid and have sharp melting point. These newly synthesized compounds have been confirmed by their elemental analysis, IR, ${ }^{1} \mathrm{H}$ NMR and mass spectral analysis. These newly synthesized compounds were screened for their antimicrobial activity against different pathogenic microbial strains and show higher to moderate antimicrobial activity against the investigated strains of bacteria and fungi.
\end{abstract}

Keywords: Glycine, Cysteine, Ethylene di amine, Tartaric acid, Antimicrobial activity

\section{Introduction}

The number of life threatening infections caused by multidrug resistant, gram positive pathogens has reached an alarming label in hospitals and community. Infection caused by these organisms create a serious challenge to the scientific community and the need for an effective therapy has let to a search for novel antibacterial agent. Many studies evaluated the biological properties of ethylenediamine and their derivatives are potent antimicrobial, antiviral, antioxidant and anti-inflammatory agent ${ }^{1,2}$. During the last decade, researchers oriented their work towards the discovery of new compounds with an improved pharmacological profile ${ }^{3-5}$ shows that the nitrogen and sulfur containing compounds are potentially active against cancer, viral and fungal diseases ${ }^{6-9}$. Amine is generally have been known to be biological active. In the view of these findings the two new compounds of tetracyclic amides of amino acid have proven to be potentially active against various fungal strains and got wide acceptance clinical trials ${ }^{10}$. The differential inhibition of cytochrome P450 between pathogenic bacteria and fungal strains and human being is the basis for the clinically important amino acid as antimicrobial agents. Further the compounds containing amide moiety has also attracted attention due to their important role in various industrial and biological processes. More over the amide moieties having fundamental interest in order to understand the role of metallo proteins in the control of cell metabolism ${ }^{11,12}$. In view of the 
important behaviour of amine and amino acid, the present communication deals with the synthesis, characterization and antimicrobial activities of some new tetracyclic amides of amino acids.

\section{Experimental}

The synthesis of amides of amino acid was carried out by the simple reaction of glycine, ethylenediamine with respective carboxylic acid in water followed by refluxing the reaction mixture for about 24 hours. The vacuum distillation of reaction mixture afforded an off white colour crystalline solid. The newly synthesized compounds have sharp melting point. The general method of preparation of some representative compounds are as follows.

Reaction of glycine and ethylenediamine with tartaric acid (Synthesis of deca cyclo 4, 5 dihydroxy 1,3,6,8 tetra-carboxy tetra-amide)

Glycine ( 2 mole, $0.2 \mathrm{M}$ ) and ethylenediamine $(1$ mole, $0.1 \mathrm{M})$ were taken in a flask fitted with an air condenser. Since the reaction is exothermic therefore the flask was kept in ice bath for half an hour before refluxion. Now the reaction mixture refluxed for 3-4 hour on a water bath followed by slow addition of an aqueous solution of tartaric acid (1 Mole $0.02 \mathrm{M}$ ). The reaction content was further refluxed again for 8-10 hours. The resulting mixture was reduced to half its volume and kept overnight, white shining crystals are obtained which was further recrystallized in ethanol.

Reaction of cysteine and ethylenediamine with tartaric acid (Synthesis of deca cyclo 4, 5 dihydroxy, 2,7, dimethylene mercapto 1,3,6,8 tetra-carboxy tetra-amide)

Cysteine $(2$ mole, $0.2 \mathrm{M})$ and ethylenediamine $(1 \mathrm{~mole}, 0.1 \mathrm{M})$ were taken in a flask fitted with an air condenser. Since the reaction is exothermic therefore the flask was kept in ice bath for half an hour before refluxtion. Now the reaction mixture refluxed for 3-4 hour on a water bath followed by slow addition of an aqueous solution of tartaric acid (1 Mole $0.02 \mathrm{M}$ ). The reaction content was further refluxed again for 8-10 hours. The resulting mixture was reduced to half its volume and kept overnight, resulting light yellow crystals are obtained which was further recrystallized in ethanol. The physical and analytical data of synthesized compounds are shown in Table 1.

Table 1. Physical and analytical data of synthesized compounds

\begin{tabular}{|c|c|c|c|c|c|c|}
\hline $\begin{array}{l}\dot{0} \\
\dot{z}\end{array}$ & compound & Compound name & $\begin{array}{l}\text { Molecular } \\
\text { formula }\end{array}$ & $\begin{array}{l}\text { Molecular } \\
\text { weight }\end{array}$ & $\begin{array}{c}\text { Melting } \\
\text { point }\end{array}$ & colour \\
\hline 1. & $\begin{array}{c}\text { Glycine + } \\
\text { Ethylenedi- } \\
\text { amine } \\
\text { +Tartaric acid }\end{array}$ & $\begin{array}{l}\text { Deca cyclo } 4,5 \text { di- } \\
\text { hydroxy } 1,3,6,8 \text { tetra } \\
\text { carboxy tetraamide }\end{array}$ & $\mathrm{C}_{10} \mathrm{H}_{16} \mathrm{~N}_{4} \mathrm{O}_{6}$ & 288.11 & 171 & White \\
\hline 2. & $\begin{array}{l}\text { Cysteine + } \\
\text { Ethylenedi- } \\
\text { amine + } \\
\text { Tartaric acid }\end{array}$ & $\begin{array}{c}\text { Deca cyclo } 4,5 \text { di- } \\
\text { hydroxy } 2,7 \text { di- } \\
\text { methylene mercapto } \\
1,3,6,8 \text { tetra-carboxy } \\
\text { tetra-amide }\end{array}$ & $\mathrm{C}_{12} \mathrm{H}_{20} \mathrm{~N}_{4} \mathrm{O}_{6} \mathrm{~S}_{2}$ & 380.08 & 196 & Yellow \\
\hline
\end{tabular}

Antimicrobial screening

The presence of antimicrobial activity of these amide of amino acids was indicated by the presence of an inhibition zone surrounding the absorbent disc impregnated with the solution 
of the tested compound. All these compounds show higher to moderate activity against pathogenic microbial strains. These nitrogen and sulfur containing compounds generally form complexes with metallo enzymes, particularly those which are responsible in basic physiology such as cytochrome oxidase and tested against different microbial strains using $10 \mu \mathrm{g} / \mathrm{mL}$ concentration of the compound. The presence of polar groups in the molecule increases the water and lipid solubility, which is necessary for biological efficacy. It may found that the compounds having nitrogen and sulfur content generally reacted with peptidoglycan layer of bacterial cell wall and damage it by pertaining it followed by death of bacterial cell.

\section{Results and Discussion}

The tetra-amides of amino acids was prepared by using following method Glycine /cysteine + Ethylene di amine + Tartaric acid -------- $\rightarrow$ Tetra- amides of amino acid the newly prepared compounds were crystallized after vacuum distillation. The compounds have sharp melting point. The further characterization of these entire compounds was done by elemental analysis, IR, NMR, Mass spectroscopy data followed by antimicrobial activity.

All the I.R. spectra of newly synthesized tetra-amides of amino acid were carried out from SAIF C.D.R.I. Lucknow. The infrared spectra were recorded in $\mathrm{KBr} / \mathrm{CsI}$ pellets in the range of 4000-450 $\mathrm{cm}^{-1}$ and the instrument was used Agilent Cary 630 FTIR spectrometer. The IR spectra of the entire compounds clearly exhibit absorption bands due to amides and methylene groups. The absorption frequencies due to carbonyl groups in amide have been fully assigned.

The NMR spectra of the compounds were carried out using Bruker Avance 400 spectrometer at SAIF C.D.R.I. Lucknow. The ${ }^{1} \mathrm{H}$ NMR spectra of the tetra-amides of amino acids were recorded in $\mathrm{CDCl}_{3}$ at room temperature using TMS as standard. The peaks values suggested the presence of secondary amides group along with methylene groups in the compound. The peak's located at $\delta 8.0 \mathrm{ppm}$ (for secondary amides) while the peaks value appears at $\delta 2.46, \delta 3.46$ and $\delta 4.09$ in case of suggested the presence of six methylene group in the compounds. The spectral data o the compounds are given in Table 2.

Table 2. Spectral data of the compounds

\begin{tabular}{|c|c|c|c|c|c|}
\hline \multirow{2}{*}{ S. No. } & \multirow{2}{*}{ Compound } & \multicolumn{3}{|c|}{ Elemental analysis } & \multirow{2}{*}{ Spectral data } \\
\hline & & $\mathrm{C} \%$ & $\mathrm{H} \%$ & $\mathrm{~N} \%$ & \\
\hline \multirow[t]{3}{*}{1.} & $\mathrm{C}_{10} \mathrm{H}_{16} \mathrm{~N}_{4} \mathrm{O}_{6}$ & 41.67 & 5.59 & 19.44 & $1.78\left(1 \mathrm{H}, \mathrm{NHCH}_{2}\right)$ \\
\hline & & & & & $7.0(2 \mathrm{H}, \mathrm{NHCO})$ \\
\hline & & & & & 9.1 brs $(1 \mathrm{H}-\mathrm{CONH})$ \\
\hline \multirow[t]{3}{*}{2.} & $\mathrm{C}_{12} \mathrm{H}_{20} \mathrm{~N}_{4} \mathrm{O}_{6} \mathrm{~S}_{2}$ & 37.88 & 5.30 & 14.73 & $1.84\left(1 \mathrm{H}, \mathrm{NHCH}_{2}\right)$ \\
\hline & & & & & $7.4(2 \mathrm{H}, \mathrm{NHCO})$ \\
\hline & & & & & $9.7 \mathrm{brs}(1 \mathrm{H}-\mathrm{CONH})$ \\
\hline
\end{tabular}

The antimicrobial activity of the amides of amino acid was carried out by the disc diffusion method using Gentamycin as standard. In this technique, filter paper (Whatmann no. 1) sterile disc of about $5 \mathrm{~mm}$. diameter impregnated with the test compounds $(10$ $\mathrm{mg} / \mathrm{mL}$ of ethanol) along with standard were placed on nutrient agar plate at $37{ }^{\circ} \mathrm{C}$ for 24 hours in BOD incubator. The inhibition zone around the dried impregnated disc was measured after 18 hours gives bactericidal activity and after 24 hours gives fungal test organisms. Following culture media have been used for growing bacteria and fungi are shown in Table 3. 
Table 3. Anti-microbial activity [Zone of inhibition ( $\mathrm{mm})$ dia \pm S.E]

\begin{tabular}{|c|c|c|c|c|c|c|}
\hline $\begin{array}{l}\dot{Z} \\
\dot{s}\end{array}$ & Compounds & $\begin{array}{c}\text { Micrococcus } \\
\text { luteus (106) }\end{array}$ & $\begin{array}{c}\text { Bacilus } \\
\text { subtilis } \\
(121) \\
\end{array}$ & $\begin{array}{c}\text { Steptococcus } \\
\text { Pneumoniae } \\
(2672)\end{array}$ & $\begin{array}{c}\text { Klebsiela } \\
\text { Pneumoniae } \\
(109)\end{array}$ & $\begin{array}{c}\text { Pseudomonas } \\
\text { Aeruginosa } \\
(424)\end{array}$ \\
\hline 1. & $\mathrm{C}_{10} \mathrm{H}_{16} \mathrm{~N}_{4} \mathrm{O}_{6}$ & $17.33 \pm 0.60$ & $1900 \pm 0.57$ & $13.00 \pm 0.50$ & $12.00 \pm 1.15$ & $18.66 \pm 0.66$ \\
\hline 2. & $\mathrm{C}_{12} \mathrm{H}_{22} \mathrm{~N}_{4} \mathrm{O}_{6} \mathrm{~S}_{2}$ & $15.66 \pm 0.33$ & $19.00 \pm 0.57$ & $11.00 \pm 0.57$ & $17.33 \pm 0.6$ & $17.00 \pm 0.57$ \\
\hline 3. & Gentamycin & $18.00 \pm 0.21$ & $18.26 \pm 0.42$ & $18.11 \pm 0.32$ & $18.08 \pm 0.28$ & $18.72 \pm 0.68$ \\
\hline
\end{tabular}

\section{Conclusion}

The two new tetra-amides of amino acid were synthesized and the structure was confirmed by IR, ${ }^{1} \mathrm{H}$ NMR, Mass spectra and elemental analysis. The two new compounds presented in the manuscript have great potential as biological activity. These findings encourage for the development of new drugs for the treatment of microbial infections along with their further aspects as gastro protective agents.

\section{Acknowledgment}

The authors are highly thankful to Dr. Nagendra Swarup, Secretary Board of Management Dyanand Shiksha Sansthan. Dr. Ashok Kumar Srivastava, Principal. Dr. Sunil Kumar Srivastava, Bursar and Dr. S. C. Dixit, Head of the Chemistry Department, D.B.S. College Kanpur for providing necessary laboratory facility. I am also thankful to UGC New Delhi for providing funding facility and CDRI Lucknow for elemental analysis, UV, IR, NMR and Mass spectral analysis and Director NBRI Lucknow for biological activity.

\section{References}

1. Albro T G, Dreifuss P A and Wormsbecher R F, J High Resolution Chromatography 1993, 16, 13-17; DOI: 10.1002/jhrc.1240160103

2. $\quad$ Fu J, Cheng K, Zhang Z, Fang R and Zhu H, Eur J Med Chem., 2010, 45(6), 26382643; DOI:10.1016/j.ejmech.2010.01.066

3. Mulongo G, Mbabazi J, Odongkara B, Twinomuhwezi $\mathrm{H}$ and Mpango G B, Res $J$ Chem Sci., 2011, 1(3), 102-108.

4. Gaspar A, Garrido E M, Esteves M, Quezada E, Milhazes N, Garrido J and Borges F, Eur J Med Chem., 2009, 44(5), 2092-2099; DOI:10.1016/j.ejmech.2008.10.027

5. Dubey D K, Pardasania D, Meehir P, Gupta A K and Rajiv J, J Chromator A, 2005, 1076(1-2), 27-33; DOI:10.1016/j.chroma.2005.04.066

6. Alam M S, Choi J H and Lee D U, Bioorg Med Chem., 2012, 20(13), 4103-4108; DOI:10.1016/j.bmc.2012.04.058

7. Spasova M, Philipov S, Nikolaeva-Glomb L, Galabov A S and Milkova T S, Bioorg Med Chem., 2008, 16(15), 7457-7461; DOI:10.1016/j.bmc.2008.06.010

8. Elemike E E, Oviawe A P, Otuokere I E, Res J Chem Sci., 2011, 1(8), 6-11.

9. Parmar K, Parajapati S, Patel R and Patel R, Res J Chem Sci., 2011, 1(1), 18-24

10. Radi S, Toubi Y, Hamdani I, Hakkou A, Souna F, Himri I and Bouakka M, Res J Chem Sci., 2012, 2(4), 40-44.

11. Jitareanu A and Tataringa G, Zbancioc A M, Tuchilus C, Balan M and Stanescu U, Res J Chem Sci., 2013, 3(3), 9-13.

12. Chandra Mohan Saxena, Archna Saxena and Naveen Kumar Shukla, Appl Natural Sci., 2014, 7(1), 88-90. 